\title{
IN MEMORIAM: JULIO C. ARMERO, PROFESOR DE FILOSOFIA DE LA UNED
}

\author{
Manuel SuANCES Marcos*
}

El pasado día tres de diciembre falleció repentinamente nuestro entrañable amigo y compańero Julio. Una vida segada en su "acmé”, en plena madurez vital y profesional. Costaba creerlo, pero el destino es implacable y así lo ha dispuesto.

Julio no tuvo una vida fácil. Siendo joven, perdió a su mujer, quedándose viudo y al cuidado de su única y pequeña hija. Soy testigo de la entereza y valentía con que afrontó esa situación y el largo periodo de su viudez. Llevaba la soledad inherente a ese estado, con un tesón y equilibrio ejemplares. Ahora le ha tocado a él marcharse precipitadamente, dejando huérfana a su joven hija.

Tras estos acontecimientos, aparece de modo singular, el carácter, talante y valor de su persona. Como compańero suyo, soy también testigo de su talla humana. Era un hombre afable, afectuoso; enseguida se empatizaba con él. Siempre sacaba el lado positivo de las cosas. Enormemente cercano, contaba chistes, chascarrillos que hacían tan amena la conversación que no llegaba el momento de ponerle fin. Tenía un carácter bondadoso; no le gustaba murmurar ni criticar a nadie. Pero su fina ironía señalaba aspectos curiosos de la gente que hacían divertida y chispeante la conversación. Los aspectos negativos de los demás los veía con condescendencia y buen humor. La verdad es que su amistad era un tesoro: entre nosotros reinaba un ambiente de mutua ayuda, echándonos una mano de comprensión y apoyo cuando las circunstancias lo requerían.

Junto a esto, quiero destacar su intuición y claridad de juicio en orden a enfocar situaciones. Era muy equilibrado y llegaba al núcleo de los problemas con una sencillez y objetividad envidiables. Nada exaltado, siempre juicioso y sensato. Por eso era de gran interés escuchar sus opiniones sobre los problemas de la universidad, de nuestra profesión docente, de la sociedad, etc...Vivía con convicción sus ideales morales, sociales y políticos respetando escrupulosamente los de los demás.

* Profesor Emérito de la Facultad de Filosofía de la UNED. 
Con este mismo talante, abordaba su trabajo docente. Era muy atento con los alumnos. Los trataba con esmero, tanto individualmente como en grupos. Pero también era muy cuidadoso en orden a la seriedad y exigencia de conocimientos en sus seminarios, trabajos de investigación, etc... En este sentido era imparcial y objetivo a la hora de enjuiciar exámenes y otras pruebas.

Como investigador estaba en su madurez. Basta con leer detenidamente su curriculum vitae para ver la brillante evolución de sus publicaciones: monografías, colaboración en libros, artículos, traducciones, reseñas, etc... Todo ello en torno al núcleo específico de su especialidad de filosofía e historia de la ciencia. Pero resulta llamativa su inquietud por muy diversos campos de la cultura. Por ejemplo, últimamente leía literatura persa y estaba también releyendo la Biblia en orden a interpretar el mensaje cristiano acercándose a las fuentes, más allá de la hermenéutica helenista en la que se gestaron sus dogmas. O sea, un espíritu científico inquieto, abierto, con "pathos” universal.

En resumen, una vida plena y fecunda, interrumpida en su momento de esplendor. Su muerte nos ha dejado tristes y con un vacío que tratamos de llenar con el afecto que no perece.

¡Querido Julio, de todo corazón, que descanses en paz! 